\title{
BIOLOGICAL AND MOLECULAR CHARACTERIZATION OF AN EGYPTIAN ISOLATE OF SOYBEAN MOSAIC VIRUS IN EGYPT.
}

\author{
Mohga M. El-Tahlawey, M. A. Amer and A. Mandour
}

Plant Virology Research Department, Plant Pathology Research Institute, A.R. C., Giza-Egypt.

\begin{abstract}
Soybean mosaic Potyviridae (SbMV) was isolated from naturally infected soybean plants cvs. Giza 111 and Giza 35 grown at Giza Research Station Farm, Agricultural Research Centre, Giza. The inoculated indicator plants gave severe mosaic on soybean cv.Giza 111, mosaic and malformation on cv Giza 35, mild mosaic on cv. Giza 22, yellow mild mosaic on cv. Giza 83, vein clearing and mild mosaic on Phaseolus vulgaris cvs Contender. Chlorotic local lesion on Chenopodium quinoa. The virus was transmitted in non-persistent manner by aphids. Electron Microscopy showed aggregates of flexuous virus particles, degenerated mitochondria and inclusions appeared as pinwheel in cytoplasm of infected soybean leaves. Dot blot immunoassay (DBIA) and indirect enzyme linked immunosorbent assays (ELISA) were used as a serological method for detection and confirmation of SbMV isolate in infected tissues.A reverse transcriptionpolymerase chain reaction (RT-PCR) method was used to detect of local isolate of SbMV in infected plants using specific oligonucleotides primer. A major RT-PCR fragment ( $340 \mathrm{bp})$ from the coat protein gene of the SbMV genome was detected.
\end{abstract}

Key words: SbMV, aphid transmission, DIBA, electron microscopy, RT-PCR

\section{INTRODUCTION}

Soybean mosaic virus (SbMV) belongs to the virus family Potyviridae Shukla et al. (1994). SbMV was first described in U.S.A. (Clinton 1915). The virus was isolated by many investigators in different countries .i.e. in U.S.A (Pacumbaba, 1995), India (Nariani \& Pingaley, 1960), Germany (Quantz, 1961), Bulgaria (Vui-Yui, 1961), Japan (Iizuka \& Yoshida, 1988), Portugal (De vasconcelos, 1964); Africa (Akhatova, 1969), Russian (Reifman \& Polivanova, 1969), Soviet Far East (Vaglav et al., 1970), Taiwan (Porto \& Hagedorn, 1974 and Iizuka et al., 1994), Brazil (Cho, et al., 1977), Korea (Rossel \& Thottapilly, 1993) and Colombia (Benscher et al., 1996). In Egypt, SbMV was isolated by many investigators (Sabek $\boldsymbol{e t}$ al., 1979; Kishtah et al., 1984 and Mandour 2002).

More than eight SbMV strains exist in Korea (Kim et al., 2000). Detection and identification of SbMV strains is very important both for soybean cultivation and breeding SbMV-resistant cultivars. Although succeeded in discriminating SbMV strain G5 from non-G5 SbMV isolates using strain specific monoclonal antibodies, they had to use three antibodies because a single monoclonal antibody that could detect a single strain had not been identified. It is still difficult to differentiate SbMV strains by serological methods because most SbMV strains are serologically homogeneous (Hill et al., 1994). Also, it is not easy to raise strain specific antibodies. Therefore, the method based on the pathogenicity of SbMV isolates on differential soybean cultivars (Kim et al., 2003) has been used widely to identify SbMV strains. However, using differential cultivars is laborious and time consuming. SbMV is a flexuous, rode not enveloped shape $d$ with a clear modal length of $700 \mathrm{~nm} ; 15 \mathrm{~nm}$ wide, the containing 5.3\% nucleic acid, $94.7 \%$ protein; and $0 \%$ lipid. The virion composed

Fayoum J. Agric. Res. \& Dev., Vol.20, No.1, January, 2006 
of mono partite plus sense single stranded RNA (ssRNA) genome polyprotein and has base composition $24.3 \%$ guanosine $(\mathrm{G}), 29.9 \%$ adenine (A), $14.9 \%$ cytosine (C), and 30.9\% uracil (U) (Hill \& Benner, 1980). The objectives of the present work aim to provide a biological and molecular characterization of an Egyption isolate of SbMV associated with diseases of soybean plants in Egypt.

\section{MATERIALS AND METHODS}

\section{I-Source of virus isolate:}

Naturally infected soybean plants (Glycine $\max$ L.) showing mosaic, yellowing, stunting, leaf curling and malformation were collected from two commercial soybean cultivars (Giza 111 and Giza 35) grown at Research Station Farm, Agricultural Research Centre, Giza. Samples were serologically checked against SbMV by indirect-ELISA according to Hobbs et al., 1987 using antisera kindly provided by Danish Government Institute of Seed Pathology, Denmark.

\section{II-Isolation of SbMV:}

Samples which reacted positively, were separated and used for mechanical inoculation to obtain the virus in relatively pure form. Single local lesion technique (Kuhn, 1964) was carried out to inoculate the local lesion host, Chenpodium quinoa. One lesion was separated, grinded in phosphate buffer and used to inoculate healthy soybean plant $c v$. Giza 111 which used as a source of virus.

\section{III- Identification of the isolated virus:}

The following was used to confirm virus identification and to characterize the SbMV isolate

\section{1- Host range and diagnostic host studies:}

Twenty six plant species and cvs belonging to four families were mechanically inoculated by the above mentioned virus infection sap obtained from infected soybean plants. Five seedlings of each test plant were used. The inoculated plants were kept under greenhouse conditions and observed for symptoms expression.

\section{2- Aphid transmission}

Non-viruliferous colonies of aphids, Myzus persicae,Sulz, Aphis fabae Scop and Aphis craccivora Koch. were maintained on Chinese cabbage seedlings in an insect proof cage. Aphids were starved for $30 \mathrm{~min}$ before they were transferred onto soybean plants infected with SbMV for $30 \mathrm{~min}$. Viruleferious aphids were transferred onto healthy soybean seedlings and left to feed for $24 \mathrm{~h}$, and then aphids were killed by sparing with 2\%Malathion. Five aphids were used for each plant and five seedlings were used for each treatment which was repeated for three times. The plants were then observed for virus symptoms after four weeks. Plants were serologically checked by indirectELISA against SbMV presence.

\section{3- Dot - Immunobinding assay (DIBA):}

The procedure of Lizarrage \& Fernandez-Northcote (1989) was followed. The leaf tissues $(0.1 \mathrm{~g})$ were ground in TBS $(20 \mathrm{mM}$ Tris bas, $500 \mathrm{mM}$ $\mathrm{NaCl}, \mathrm{pH} 7.5)$ in a 1: $10(\mathrm{w} / \mathrm{v})$ ratio and centrifuged at $12000 \mathrm{rpm}$ at $4{ }^{\circ} \mathrm{C}$ in a microcentrifuge. The membrane was soaked in TBS containing $1 \%$ bovine serum albumin (BSA) overnight at room temperature and reacted with SbMV specific antirabbit antibody conjugate with alkaline phosphatase. The membrane was subjected to extensive washing in TBS buffer containing $0.1 \%$ Tween-20 and the reaction visualized by incubation in color solution (NBT/BCIB) as substrate.

\section{4- Electron microscopy (Ultra-thin sections)}

One-millimeter diameter disks were punched out from five young leaflets of soybean plants infected with SbMV. Disks were fixed and processed for electron microscopy according to Spurr (1969). Thin sections were cut from

Fayoum J. Agric. Res. \& Dev., Vol.20, No.1, January, 2006 
selected pieces of the embedded tissue stained with uranyl acetate and lead citrate and viewed with a Philips EM300 electron microscope, Ain Shams Specialized Hospital.

\section{5-Total RNA extraction from plant tissues and RT-PCR:}

Viral RNA was isolated using the RNA isolation system (Promega, Corp., Madison, WI) according to the manufacture's instructions. The complementary primer [MV1 5'-ATGCACACTCTTTTGGGCATGGGT-3'] and homologous primer [MV2 5'-GACAACAAATATTGCCGTACCTC-3'] specific for SbMV were used according to Chen et al. (2004). This pair of oligonucleotides amplifying a 340 bp fragments. RT-PCR was performed in 50 $u l$ reaction mixtures containing $10 u l$ of AMV/ TFi $5 \mathrm{X}$ reaction buffer, $1 u l$ of dNTP $(10 \mathrm{mM}$ each); $2 u l$ of MgSO4 $(25 \mathrm{mM}) ; 1 \mathrm{ul}$ of each primer $(50 \mathrm{pmol})$; I $u l$ of AMV reverse transcriptase $(10 \mathrm{U} / u l) ; 1 u l$ of TFi DNA polymerase ( $5 \mathrm{U} l$ $/ u l)$ and $5 u l$ of the template RNA. Thermocycling was programmed as follows: cDNA synthesis at $48^{\circ} \mathrm{C}$ for $45 \mathrm{~min}$ and RNA /cDNA primer denaturation at 94 ${ }^{\circ} \mathrm{C}$ for $2 \mathrm{~min}$ followed by 35 cycles for template denaturation at $94^{\circ} \mathrm{C}$ for $30 \mathrm{sec}$, primer annealing at $60^{\circ} \mathrm{C}$ for $1 \mathrm{~min}$ and extenstion at $72^{\circ} \mathrm{C}$ for $2 \mathrm{~min}$ and a final extenstion at $72^{\circ} \mathrm{C}$ for $7 \mathrm{~min}$.

Analysis of RT-PCR amplified products:

Aliquots of 5 ul of RT-PCR amplified products were analysed on $1 \%$ agarose gel in TBE buffer $(89 \mathrm{mM}$ Tris- $\mathrm{HCl}, 89 \mathrm{mM}$ boric acid, $2.5 \mathrm{mM}$ EDTA, $\mathrm{pH} 8.3$ ) at $100 \mathrm{~V}$ for $1 \mathrm{~h}$. gel was stained with ethedium bromide. DNA Molecular Weight Marker IX (Roche Diagnostics GMBH) was used to determine the size of RT-PCR amplified products.

\section{RESULTS AND DISCUSSION \\ Isolation and symptomatology}

Naturally infected soybean plants showed mosaic, yellowing, stunting, leaf curling and malformation were collected from cvs Giza 111 and Giaza 35 growing at Research Station Farm, ARC, Giza during the growing season 2005. Samples which showed symptoms doubted to be SbMV, reacted strongly positive with indirect ELISA using antisera specific for SbMV. SbMV was successfully biologically purified from single local lesion induced on Chenopodium quinoa 6-8 days after inoculation (Fig1). The purified virus isolate gave positive reaction when tested by indirect ELISA.

\section{Identification of the isolated virus:}

The isolated virus was identified as SbMV according to diagnostic host reaction, aphid transmission, electron microscopy, serological test and RT-PCR. Data presented in Table (1) reveal that out of 26 plants belonging to 14 species, 10 plants belonging to 4 species were susceptible to infection with SbMV. Among these plants, only one reacted by producing local lesions while the other 9 showed different types of systemic symptoms. Back inoculation from plants without symptoms to the indicator host revealed that they were virus-free. Indirect ELISA test ensured these results. It is clear from the obtained data that the hosts which react with the virus are belonging to Fabaceae and Chenopodiaceae. Concerning Fabaceae, Glycine max reacted with systemic symptoms ranging from vein clearing and mosaic (in case of Clark cv.), to mosaic (in case of Giza 111 and Giza 22 cvs.), to yellowing and mild mosaic symptoms (in case of Giza $83 \mathrm{cv}$.), mild mosaic (in case of Giza $35 \mathrm{cv}$.) In case of Phaseolus vulgaris, cultivar Giza $3 \mathrm{cv}$. gave mild mosaic symptoms and Pinto cv. gave vein yellowing and mild mosaic symptoms (Fig 1) and Sub blanc and Top crop cvs, gave no symptoms regard Pisum sativum it reacted with systemic symptoms from yellowing and mosaic in case of Lin clor and mild mosaic in case Tomas laxston cv.. Concerning Chenopodium quinoa it reacted

Fayoum J. Agric. Res. \& Dev., Vol.20, No.1, January, 2006 
with chlorotic local lesions All the plants of Cucurbitaceae and Solanaceae tested and the other Fabaceae plants gave no symptoms.

This study deals with soybean mosaic virus, which was isolated from naturally grown soybean plants in Egypt. Host range studies indicated that the virus evoked vein clearing and mosaic on soybean Clark $c v$., mosaic on Giza 111 and Giza $22 \mathrm{cvs}$., yellowing and mild mosaic on Giza $83 \mathrm{cv}$, mild mosaic on Giza $35 c v$ (Fig 2), mild mosaic on Phaseolus vulgaris Giza $3 c v$. and vein yellowing and mild mosaic Pinto $c v$., yellowing and mosaic on Pisum sativum Lin clor $c v$., and mild mosaic on Tomas laxston $c v$., chlorotic local lesions on Chenopodium quinoa (Fig 1). These results are in agreement with those obtained by Nariani \& Pingaley, 1960; Akhatova, 1969; Cho, et al., 1977; Kishtah et al., 1984; Iizuka, et al., 1994; Benscher, et al., 1996 and Mandour 2002).

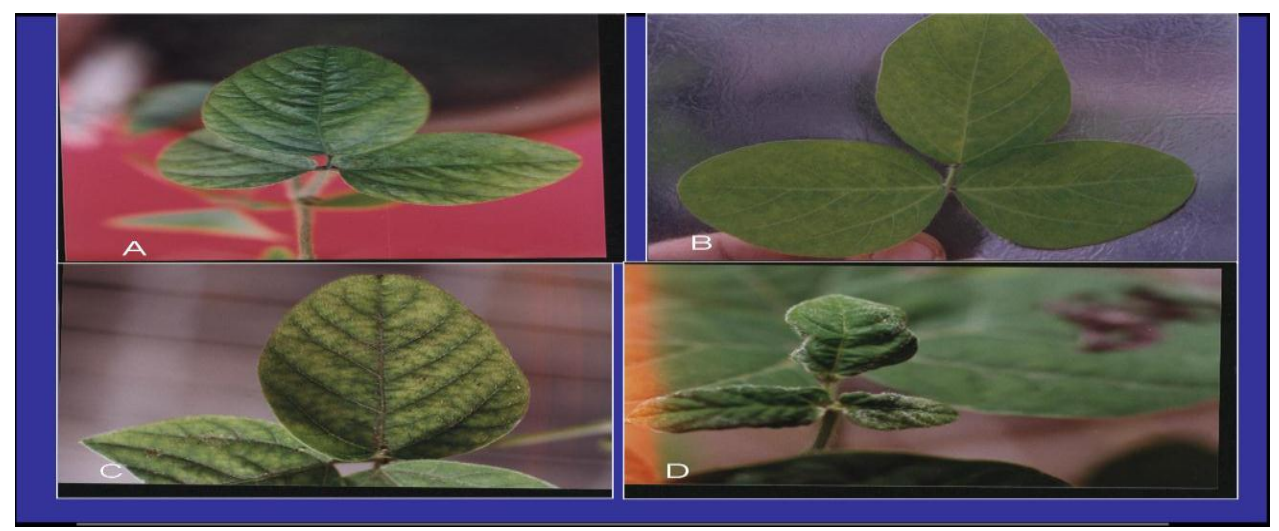

Fig (1) Symptoms of SbMV on soybean plants cvs. (A) Giza35 mild mosaic, (B) Giza111 mosaic, (C) Giza 83 yellowing and mosaic, (D) Clark. malformation and mosaic.

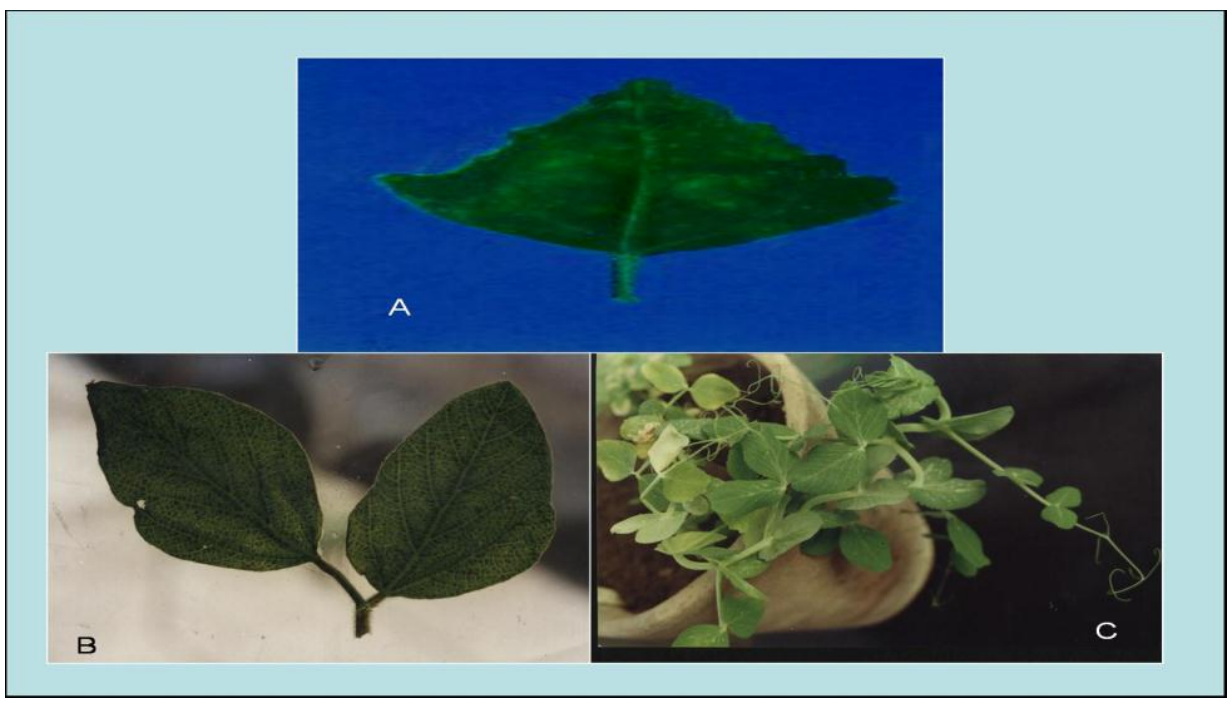

Fig (2). (A) Symptom of SbMV on (Ch. quinoa) chlorotic local lesions, (B) Symptoms of SbMV on (Phaseolus vulgaris) cv. Giza 3 mild mosaic, (C) Symptom of SbMV on (Pisum sativum) $\mathrm{cv}$. Lin clor yellowing and mosaic.

Fayoum J. Agric. Res. \& Dev., Vol.20, No.1, January, 2006 
Regarding to insect transmission, five viurileferous of Myzus persica can transmit SbMV, in non- persistent manner from the tested plants after 30 min acquisition and $1 \mathrm{~h}$ inoculation feeding periods. Results shown in Table (2) indicated that SbMV was transmitted also by Aphis craccivora and A. fabae. In this study, for SbMV aphid transmission, M. persica was found to be more efficient than $A$. fabae and A. cracceivora insects when they allowed to feed on soybean infected plants. The rewspective averages of infeted plants were 77.5, 32.5 and $25 \%$, respectively. This result was confirmed by the findings of Sabek, et al. (1979); Morales, et al. (1990); Kosaka \& Fukunishi (1993); Benscher et al. (1996) and Mandour (2002).

Table (1). Reaction of different plants to SbMV inoculation.

\begin{tabular}{|c|c|c|c|}
\hline Inoculated plants & Symptoms & Infection & $\begin{array}{l}\text { Indirect } \\
\text { ELISA }\end{array}$ \\
\hline $\begin{array}{l}\text { Family:- Fabacea } \\
\text { Glvcine } \max \end{array}$ & & & \\
\hline Clark & $\mathrm{VC}+\mathrm{Mo}$ & + & + \\
\hline Giza 111 & Mo & + & + \\
\hline Giza 22 & Mo & + & + \\
\hline Giza 83 & $\mathrm{Y}+\mathrm{MMo}$ & + & + \\
\hline Giza 35 & MMo & + & + \\
\hline Phaseolus vulgaris cvs & & & \\
\hline Giza 3 & MMo & + & + \\
\hline Sub blanc & 0 & - & - \\
\hline Top crop & 0 & - & - \\
\hline Pinto & $\mathrm{VY}+\mathrm{MMo}$ & + & + \\
\hline Vicia faba cvs. Giza 716 & 0 & - & - \\
\hline Giza 3 & 0 & - & - \\
\hline Giza 204 & 0 & - & - \\
\hline $\begin{array}{l}\text { Vigna unguiculata cvs } \\
\text { Creame } 97\end{array}$ & 0 & - & - \\
\hline Creame use & 0 & - & - \\
\hline Crème 7 & 0 & - & - \\
\hline Pisum sativum cvs & V & & \\
\hline $\begin{array}{l}\text { Lin clor } \\
\text { Tomas laxston }\end{array}$ & Y+Mo & + & + \\
\hline & MMo & + & + \\
\hline & 0 & - & - \\
\hline $\begin{array}{l}\text { Irifolium pretense } \\
\text { Family:- Cucurbitaceae }\end{array}$ & 0 & - & - \\
\hline Cucurbita pepo & 0 & - & - \\
\hline Family:- Chenopodiaceae & & & \\
\hline C.amarnticolor & 0 & - & - \\
\hline C.quinoa & Ch.LL & + & + \\
\hline $\begin{array}{r}\text { Namicotiana tabacum } \\
\text { Niculaceat }\end{array}$ & 0 & - & - \\
\hline N. glutinosa & 0 & - & - \\
\hline N. clevelandii & 0 & - & - \\
\hline$N$.a rusica & 0 & - & - \\
\hline
\end{tabular}

* MMo= Mild mosaic, $\mathrm{Mo}=$ Mosaic, $\mathrm{Y}=$ Yellowing, $0=$ No symptoms, $\mathrm{VC}=$ Vein clearing, YV= Vein yellowing, Ch. LL = Chlorotic local lesion.** As determined by ELISA test $+=$ ELISA positive reaction, $-=$ ELISA negative reaction.

Fayoum J. Agric. Res. \& Dev., Vol.20, No.1, January, 2006 
Mohga M. El-Tahlawey, et al.

Table (2). Precentage of transmission of SbMV from infected soybean to healthy soybean plants by viruleferous Aphids:

\begin{tabular}{|l|c|c|c|}
\hline Aphid & No. of inoculated plant & No. of infected plant & \% infection \\
\hline $\begin{array}{l}\text { Myzus } \\
\text { persicae }\end{array}$ & 40 & 31 & 77.5 \\
\hline $\begin{array}{l}\text { Aphis } \\
\text { craccivora }\end{array}$ & 40 & 10 & 25 \\
\hline Aphis fabae & 40 & 13 & 32.5 \\
\hline
\end{tabular}

Dot - Immunobinding assay (DIBA):

Dot-blot-immunoassay of total protein extracted from SbMV infected tissues. 12 samples collected from open field are positively reacted with SbMV antisera diluted 1-1000. The total proteins were extracted in phosphate buffer and 10 microliters of each were spotted on the nitrocellulose membrane. The membrane was immune-developed using 1-1000 dilution of SbMV antiserum as first antibody and 1-7500 dilution of anti- rabbit-alkaline phosphatase conjugated as second antibody. The colour was developed after 5-15 minutes using BCIPNBT substrate. Row No 4: (Negative) the healthy plant shows no signal. (Fig 2).

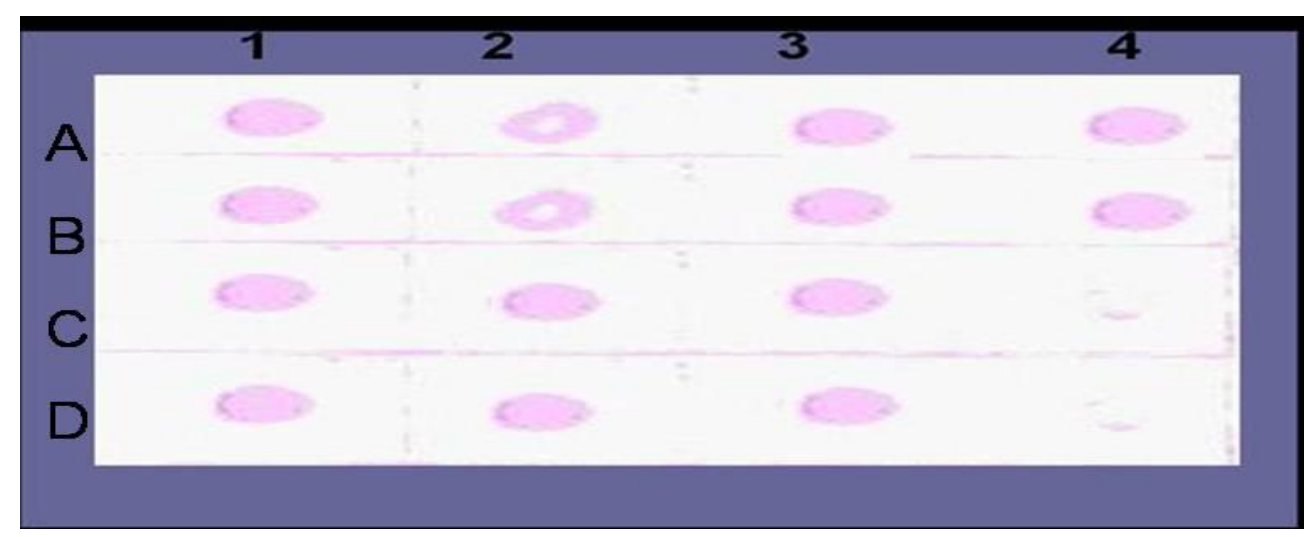

Fig (3): Dot blot immunoassay for detection of SbMV in infected plant tissue (Row 1, Row 2 and Row 3 A,B,C and D). No reaction was observed between the anteserum and uninfected plant tissue ( Row 4 C \&D).

\section{Electron microscopic examination}

The ultra-thin section of SbMV-infected leaves showed aggregates filamentous virus particles, degenerated mitochondria and pinwheel (characteristic for SbMV), in the cytoplasm, representing Potyviridae group (Fig 4). Electron Microscopy studies reveal that SbMV has been observed the formation of inclusion bodies which associated with SbMV infection.

Similar results were reported by Tu, (1973 and 1976); Morales et al. (1990) and Mandour (2002) who reported that SbMV induces the formation of inclusion bodies and virus particles aggregates in the cytoplasm.

Fayoum J. Agric. Res. \& Dev., Vol.20, No.1, January, 2006 


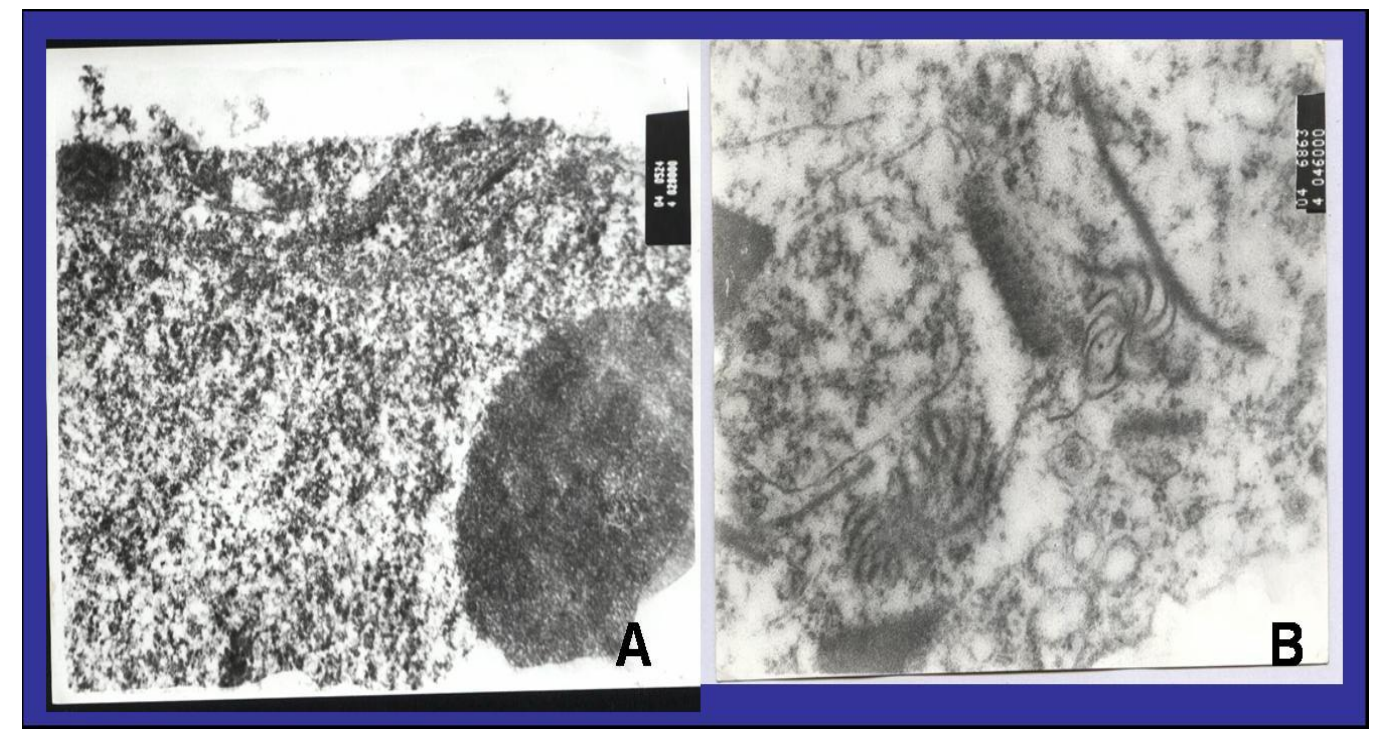

Fig (4) .(A) The ultra-thin section of SbMV-infected leaves showed aggregates filamentous virus particles, (B) Inclusion pinwheel, degenerated mitochondria and virus aggregates in cytoplasm of soybean leaf cells infected with SbMV.

\section{Detection of SbMV using RT-PCR:}

RT-PCR was performed on total RNA extracted from $30 \mathrm{mg}$ infected and uninfected plant materials using SV- Total RNA Isolation System. The RNA was reverse transcripted by AMV reverse transcriptase. The reverse transcription reaction was primed with the complementary primer specific for SMV. The resulting complementary DNA ( cDNA) was amplified by PCR after adding the complemantary and homologous primers. The expected size is $340 \mathrm{bp}$. Obtained data in Fig (5) illustrate the agarose gel electrophoresis of RT-PCR amplified SbMV-CP cDNA from infected soybean Giza $35 \mathrm{cv}$. (lane $1 \mathrm{cv}$.Phaseolus vulgaris Giza $3 c v$. (lane 2); soybean leaves Giza $111 c v$. (lane 3). No amplified fragments of cDNA were obtained from uninfected soybean leaves Giza $35 \mathrm{cv}$. (lane 4).

PCR is an extremely sensitive and specific technique for the amplification of genomes, and became widely used as adiagnostic technique for infection by phytoplasma (Schaff $\boldsymbol{e t}$ al., 1992), bacteria (Minsavage et al., 1994), viroids (Rezaian et al.,1992) and plant viruses belonging to several different groups (e.g.,the geminiviruses, luteoviruses and potyvirus groups (Henson and French, 1993; Langeveld et al., 1991; Robertson et al., 1991 and Rojas et al., 1993) .RT-PCR has been used to detect plant viruses (Singh $\boldsymbol{e t}$ al., 1995). The assay has been applied to enhance detection sensitivety of potyviruses such as plum pox virus (Wetzel et al., 1991) sugarcane mosaic virus (Smith and Van de Velde, 1994), zucchini yellow mosaic virus (Thomson et al., 1995) , two sweet potato viruses (Colinet et al., 1994 ) and SbMV (Omunyin et al., 1996). 


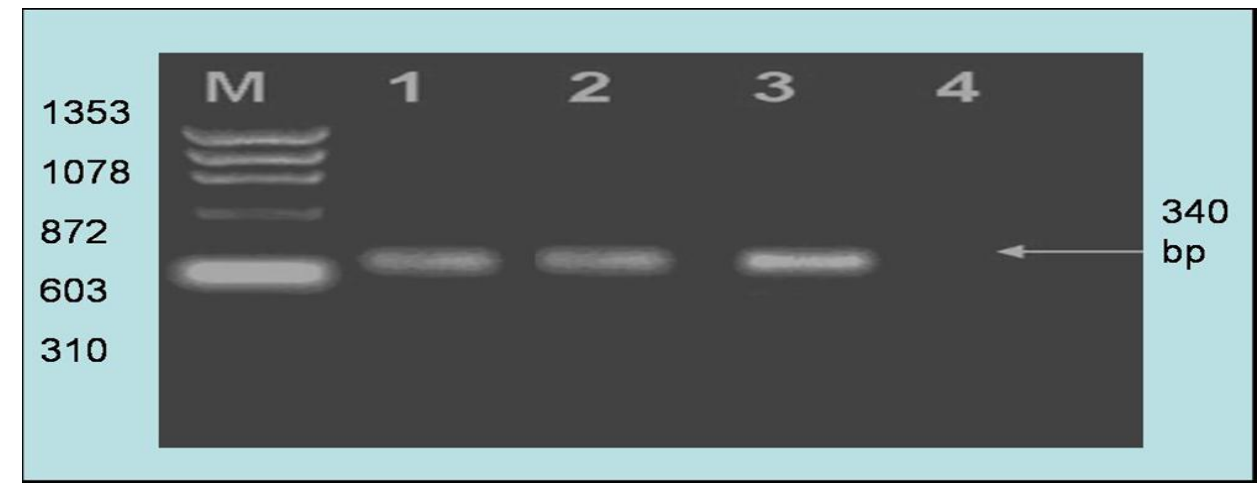

Fig. (5 ): 1.2\% agarose gel electrophoresis showing PCR amplification of SbMV using specific SbMV1 and SbMV2 primers ( 340 bp) from infected soybean Giaza 35 cv. ,infected Phaseolus vulgaris Giza $3 \mathrm{cv}$. and soybean leaves Giza $111 \mathrm{cv}$. (lane1 2 and 3). Healthy soybean plants showing no amplified product (lane 4). M: DNA Molecular Weight Marker IX (Roche Diagnostics GMBH).

\section{REFERENCES}

Akhatova, F.K. (1969). Soybean mosaic (in Russian), Vest. Soil. Khoz. Nauk Alma-Aea. 12 (5): 79-82 (English summary in an annotated bibliography of soybean diseases, 1882-1974. J.N. Sinclair \& O.D. Dhingra, 1975); P. 72.

Benscher. D, Pappu, S.S.; Niblett, C.L.; Varon. De. Agudelo, F.; Morales, F.; Hodson, E.;Alvarez, E.; Acosta, O.; Lee, R.F.and De. Agudelo, F.V. (1996). A strain of soybean mosaic potyvirus infecting Passiflora spp. in Colombia. Plant Dis., 80 (3): 258 - 262.

Chen, J.; Zheng, H.Y.; Lin, L.; Adams, M.J.; Antoniw, J.F.; Zhao, M. F.; Shang,Y.F. and Chen, J.P. (2004). A virus related to soybean mosaic virus from Pinellia ternate in China and its comparison with local SbMV isolates. Arch. Virol., 149 (2) : 349-363.

Cho, E.K.; Chung, B.J. and Lee, S.H. (1977). Studies on identification and classification of soybean virus diseases in Korea. II. Etiology of a necrotic disease of Glycine max. Plant. Dis. Rept., 61: 313 - 317.

Clinton, G.P. (1915). Notes on plant diseases of Connecticut. Connecticut State Agr. Expr. Sta. Ann. Rept. 1915: 446 - 447.

Colinet, D.; J. Kummert; R.; Lepoivre and Semal, J. (1994). Identification of distinct potyviruses in mixedly- infected sweetpotato by the polymerase chain reaction with degenerate primers. Phytopathology, $84: 65-69$.

De vasconcelos, F.A.T. (1964). Contribuicao para o estudo virus do mosaico da soja. Anais Do Instituto Superior De Agronom ,26: 181 221.

Henson, J.M. and French, R. (1993). The polymerase chain reaction and plant disease diagnosis. Ann. Rev. Phytopathology ,31: 81-89.

Hill, J.H. and Benner, H.I. (1980). Properties of soybean mosaic virus and its isolated protein. Phytopathol. Z., 97: $272-281$.

Hill, J.H.; Benner, H.I. and Van Deusen, R.A. (1994). Rapid differentiation of soybean mosaic virus isolates by antigenic signature analysis. J. Phytopathol., 142:152-162.

Fayoum J. Agric. Res. \& Dev., Vol.20, No.1, January, 2006 
Hobbs, H. A.; Reddy, D. V. R.; Rasjeshwari, R. and Reddy, A. S. (1987). Use of direct antigen coating and protein a coating ELISA procedures for detection of three peanut viruses. Plant Dis., 71: 747749.

Iizuka, N.; Charchar, M.J.D. and Charchar, M.J.d. A. (1994). Classification of strains of soybean mosaic virus and seed transmissibility. Relatorio. Tecnico. do. Proje to. Nopo. Brasileiro. de. Cooperacao. em. Pesquisa. Agricola. Nos. cerrados. 1987-1992. ref $226-236$.

Kim, Y. H.; Kim, O. S.; Lee, B. C.; Im, D. J. and Choi, J. K. (2000). Distribution and diversity of soybean mosaic virus strains in Korea. Korean J. Plant Pathol., 16:179.

Kim, Y. H.; Kim, O. S.; Lee, B. C.; Moon, J. K.; Lee, S. C. and Lee, J. Y. (2003). G7H, a New soybean mosaic virus strain: Its virulence and nucleotide sequence of CI gene. Plant Dis., 87:1372-1375.

Kosaka, Y. and Fukunishi, T. (1993). Attenuated isolates of soybean mosaic virus derived at a low temperature. Plant Dis., 77: 882 - 886.

Kishtah, A. A.; Tolba, M. A.; El-Sherbeeny, M. H.; Hassan, M. Z. and Safia Abdalla, T. (1984). Studies on some soybean culitvars and lines resistant to soybean mosaic virus in Egypt. Agricultural Research Review, 62. (2): 347 - 352.

Kuhn, C. W. (1964). Separation cowpea virus mixtures. Phytopathology ,54: 739-740.

Langeveld, S. A. ;Dore, I. M.; Memelink, I.; Derks, A.R.L.M.; C.I.M. Van der Vlugt, C.I. M.; Asjes, C.J. and Bol, J.E. (1991). Identification of potyviruses using polymerase chain reaction with degenerate primers. J. gen. Virology, $72: 1531-1541$.

Lizarrage, C. and Fernandez-Northcote, E.N. (1989). Detection of potato virus $\mathrm{X}$ and $\mathrm{Y}$ in sap extracts by amodified indirect enzyme linked immunosorbent assay on nitrocellulose membranes (NCMELISA). Plant Dis. 73 : 11-14.

Mandour, A. M. (2002). Studies on effect of environmental factors on some soybean viruses. M.Sc. Thesis. Institute of Environmental Studies and Research. Ain Shams University.

Minsavage, G. V.; Thomson, C. M.; Hopkins, D. L. ;Leite, R. M. V. C. and Stall, R. E. (1994). Development of a polymerase chain reaction protocol for detection of Xylella fastidiosa in plant tissue. Phytopathology, $84: 461-456$.

Morales, F. J; Messen, A. I; Castano, M. and Calvert, L. (1990). Detection of a strain of soybean mosaic virus affecting tropical forage species of Centrosema. Plant Dis., 74: 648 - 651.

Nariani, T. K. and Pingalely, K. V. (1960). A mosaic diseases of soybean (Glycine max (L.) Merr.) Ind. Phytopath., 13: 130 - 136.

Omunyin, M.E.; Hill, J.H. and Miller, W.A. (1996). Use of unique RNA sequence specific oligonucleotide primers for RT-PCR to detect and differentiate soybean mosaic virus strain. Plant Dis., 80 : 1170-1174.

Pacumbaba, R.P. (1995). Seed transmission of soybean mosaic virus in mottled and non-mottled soybean seeds. Plant Dis., 79 (2): 193 195.

Fayoum J. Agric. Res. \& Dev., Vol.20, No.1, January, 2006 
Porto, M.D. and Hagedorn, D.J. (1974). Susceptibility of Phaseolus lathyroides to soybean mosaic virus. Plant Dis. Reptr., 58: 322 - 326.

Quantz, L. (1961). Investigations on the common bean mosaic and the soybean virus. Phytopathol. Z., 43: $79-101$.

Reifman, V.G. and polivanova, T.A. (1969). [Virus diseases of soybean in Soviet Far East.] Trudy Biol-pochy. Inst. Dal-Nevost fil Sib. otd. ANSSR : $83-104$.

Rezaian M.A.; Krake, L.R. and Golino, D.A. (1992). Common identity of grapevine viriods from USA and Australia revealed by PCR analysis . Intervirology, $34: 38-43$.

Robertson, N.L; French, R. and Gray, S.M. (1991). Use of group specific primers and polymerase chain reaction for the detection and identification of luteoviruses. J. gen. Virology, 72 : 1473-1477.

Rojas, M.R.; Gilbertson, R.L.; Russell, D.R. and Maxwell, D.R. (1993). Use of degenerate primers in the polymerase chain reaction to detect whitefly transmitted geminiviruses. Plant Dis., 77 : 340347.

Rossel, H.W. and Thottappilly, G. (1993). Seed transmission of viruses in soybean (Glycine max) in relation to sanitation and international transfer of improved germplasm. Seed Sci. and Technol., 21 (1): 25 30.

Sabek, A. M.; Tolba, M. A. and Kishtah, A. A. (1979). Two strains of soybean mosaic virus isolated from naturally infected soybean $3^{\text {ed }}$ Egypt Phytopathol. Congress 117 - 129.

Schaff, D.; Lee, I. and Davis, R.E. (1992). Sensetive detection and identification of mycoplasma- like organism in plants by polymerase chain reaction . Biochem. Biophys. Res. Commun., 186 : 1503-1509.

Shukla, D. D.;Ward, C. W. and Brunt, A. A. (1994). The Potyviridae. CAB International, Wallingford, UK.

Singh, R. P.; Kurz, J. and Boiteau, G. (1995). Detection of stylet-biorne and circulative potato viruses in aphids by duplex reverse transcription polymerase chain reaction. J. Viro. Methods, 55 : 133143.

Smith, G.R. and Van de Velde, R. (1994). Detection of sugarcane mosaic virus and fiji disease virus in diseased sugarcane using the polymerase chain reaction. Plant Dis., $78: 557-561$.

Spurr, A. R. (1969). A low viscosity epoxy resin-embedding medium for electron microscopy. Ultrastruc. Res. $26-31$.

Thomson, K.G.; Dietzgen, R.G.; Gibbs, A.J.; Tang, Y.C.; Liesack, W.; Teakle, D.S. and Stackebrandt, E. (1995). Identification of zucchini yellow mosaic potyvirus by RT-PCR and analysis of sequence variability. J. Virol. Methods, 55: 83-96.

Tu, J.C. (1973). Electron microscopy of soybean root nodules infected with soybean mosaic virus. Phytopathology, 63: $1011-1017$.

Tu, J.C. (1976). Localization of infections of soybean mosaic virus, it mottled soybean seeds. Microbiol., 14: 150 - 151.

Vaglav, V.; Radman, L.; Batinica, J.; Ristanovic, M.; Dimic, N.; Numic, R. and Bes, A. (1970). Contributions to the knowledge of diseases and pests of soybean in the productive regions of Bosnia. Zashtita Bilja, 21: 229 - 236.

Fayoum J. Agric. Res. \& Dev., Vol.20, No.1, January, 2006 
Vui-Yui, D. (1961). The mosaic disease of the soybean varieties in Bulgaria [in Russian, English summary]. Rast. Zasht. (Bulgaria), 9: $20-26$.

Wetzel, T.; Candresse, T.; Ravelonardo, M. and Dunez, J. (1991). A polymerase chain reaction assay adapted for plum pox potyvirus detection. J. Virol. Methods, $33: 355-365$.

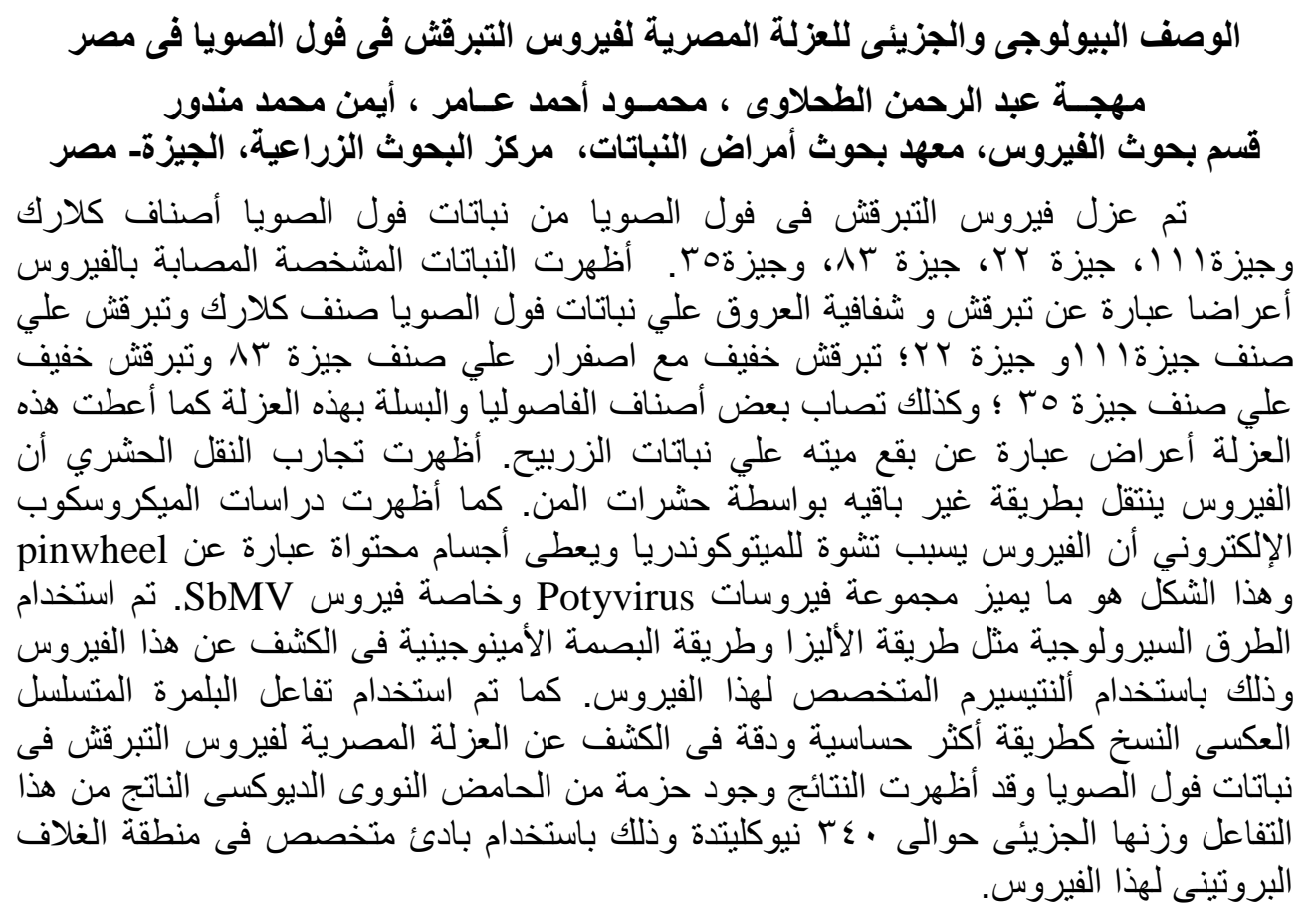

Fayoum J. Agric. Res. \& Dev., Vol.20, No.1, January, 2006 